\title{
Title: Effective treatment of folliculitis decalvans with ciclosporin: a case series
}

Word count: 650

Figure count: 1

Table count: 1

Key words: systemic immunosuppression, therapeutics, cicatricial alopecia

\section{Authors:}

1. Dr. Rebekka Jerjen (corresponding author), BMSc (Hons), MChD (Dist)

Affiliation: Sinclair Dermatology, Melbourne, VIC, Australia

Address: Sinclair Dermatology

2 Wellington Parade

East Melbourne, 3141

Victoria, Australia

Email: Rebekka.jerjen@gmail.com

Tel: +61405013585

2. Dr. Nekma Meah, MBChB, MRCP (UK), MRCP (Derm)

Affiliation: Sinclair Dermatology, Melbourne, VIC, Australia

3. Dr. Lara Trindade de Carvalho, MD

Affiliation: Sinclair Dermatology, Melbourne, VIC, Australia

4. Dr. Dmitri Wall, MB BCh, MRCP

Affiliation: Sinclair Dermatology, Melbourne, VIC, Australia

5. Dr Shyamalar Gunatheesan, BMSc, MBBS, FACD

Affiliation: Sinclair Dermatology, Melbourne, VIC, Australia

5. Prof. Rodney Sinclair*, MBBS, MD, FACD

Affiliation: Sinclair Dermatology, Melbourne, VIC, Australia

* Dr. Sinclair is a current Australasian Journal of Dermatology Editorial Board Member (COI)

No funding was received for this article

This is the author manuscript accepted for publication and has undergone full peer review but has not been through the copyediting, typesetting, pagination and proofreading process, which may lead to differences between this version and the Version of Record. Please cite this article as doi: 10.1111/AJD.13532

This article is protected by copyright. All rights reserved 
Acknowledgments: None

\section{Conflicts of interest disclosure:}

Dr. Wall reports an Honoraria from Janssen, grants from Pfizer, consultancy with Eli-Lilly, all outside the submitted work.

Dr. Sinclair is a current Australasian Journal of Dermatology Editorial Board Member (COI)

Dr. Sinclair reports being a member of, on the International advisory board of, and principal investigator in sponsored clinical trials for Pfizer and Eli Lily. He is founder, director and principal investigator in clinical trial for Samson clinical. He has been/is currently a principal investigator in clinical trials for Jaansen, Sun Pharma, Arena, Demira, Astra Zenica, Novartis, Merck, Sanofi, Abbvie, Galderma, Prinicipia, Reistone Pharma and Aclaris.

Dr. Sinclair is a current Australasian Journal of Dermatology Editorial Board Member (COI)

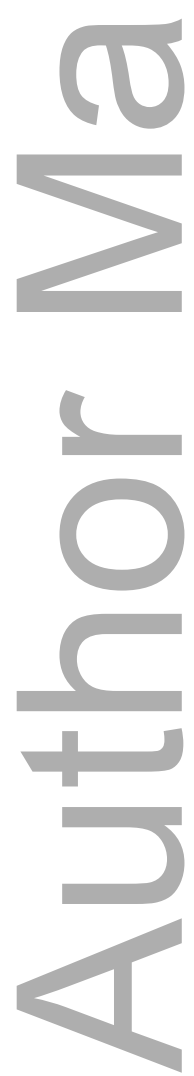

This article is protected by copyright. All rights reserved 
DR. REBEKKA BARBARA JERJEN (Orcid ID : 0000-0002-7749-1069)

DR. LARA TRINDADE DE CARVALHO (Orcid ID : 0000-0001-8540-0983)

PROF. RODNEY SINCLAIR (Orcid ID : 0000-0001-6751-1428)

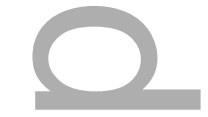

-

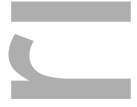

Article type : Case Letter

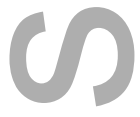

Effective treatment of folliculitis decalvans with ciclosporin: a case series

Folliculitis decalvans is a neutrophilic, cicatricial alopecia that preferentially affects the scalp vertex and occiput. Therapy aims to arrest inflammation and prevent hairloss. Response to antibiotic and anti-inflammatory treatments is unpredictable, resulting in a sometimes chronic, recalcitrant course. ${ }^{1}$ We report three patients with refractory folliculitis decalvans responding to ciclosporin. In the absence of a validated outcome measure for folliculitis decalvans, we considered photographic and symptomatic improvement; maintenance of the same therapeutic dose; and ability to taper therapy in assessing treatment response.

Case 1:

A 60-year-old Caucasian male had a 5-year history of treatment-resistant folliculitis decalvans affecting the vertex (Table 1$)$. Ciclosporin $25 \mathrm{mg}$ twice daily $(0.81 \mathrm{mg} / \mathrm{kg}$ ) was added to finasteride, oral minoxidil, minocycline and topical clindamycin. After 2 months, symptoms started improving, at 9 months good disease control was achieved without adverse effects. Ciclosporin was slowly withdrawn after a total of 19 months of therapy, with relapse noted 5 months after discontinuation.

Case 2:

A 63-year-old Caucasian female had a 4-year history of persistent folliculitis decalvans affecting the mid- and frontal-scalp. Previous treatments (listed in Table 1) were only partially effective. Ciclosporin $25 \mathrm{mg}$ twice daily $(0.83 \mathrm{mg} / \mathrm{kg}$ ) was initiated alongside low dose isotretinoin $(10 \mathrm{mg}$ 
daily), topical clindamycin and oral prednisolone (tapered and stopped after 4 weeks). A significant reduction in inflammation, pustules and symptoms was achieved after 1 month and complete resolution was seen following 12 months of combination treatment. Worsening renal impairment, however, necessitated ciclosporin discontinuation with subsequent relapse 4 months later.

Case 3:

A 30-year-old African male with a 9-year history of severe folliculitis decalvans was commenced on ciclosporin $50 \mathrm{mg}$ twice daily $(1.5 \mathrm{mg} / \mathrm{kg})$ after failing to respond to antibiotics and isotretinoin (Table 1). Ciclosporin was increased to $125 \mathrm{mg}(1.85 \mathrm{mg} / \mathrm{kg})$ and then $150 \mathrm{mg}$ daily $(2.25 \mathrm{mg} / \mathrm{kg})$ at 2 and 4 months respectively. Concomitant therapy included oral minoxidil and antiseptic shampoo. Treatment was well tolerated and a marked improvement was noted clinically and symptomatically at 6 month review (Figure 1). Though relapse occurred following treatment discontinuation by the patient, reintroduction of ciclosporin at $50 \mathrm{mg}$ twice daily promptly re-established control.

Ciclosporin, a calcineurin inhibitor, is used to prevent organ transplant rejection and prescribed for a range of inflammatory disorders including psoriasis, atopic dermatitis and rheumatoid arthritis. ${ }^{2}$ Though there are reports of single cases, ${ }^{3}$ to our knowledge, this is the first case series reporting folliculitis decalvans response to systemic ciclosporin. Limited evidence also exists for the effectiveness of ciclosporin in other cicatricial alopecias, including lichen planopilaris and discoid lupus erythematosus. ${ }^{1}$

Ciclosporin inhibits the transcription factor NF-AT, preventing production of cytokines with key roles in cutaneous inflammation such as Interleukin-(IL-)2, IL-4, Interferon (IFN)- $\gamma$ and Tumor necrosis factor (TNF)- $\alpha .{ }^{4}$ IFN- $\gamma$ is diffusely distributed in the dermis and follicular epithelium of folliculitis decalvans, albeit, to a lesser extent than in lichen planopilaris and alopecia areata. ${ }^{4}$ Additionally, inhibition of IL-2 by ciclosporin reduces activation and proliferation of TIymphocytes. In folliculitis decalvans, the activation of resident skin T-lymphocytes by microbial antigens and/or superantigens prompting release of several proinflammatory and profibrotic factors is postulated central to disease pathogenesis. ${ }^{4}$ Consequently, it is plausible that ciclosporin can disrupt the pro-inflammatory and T-cell-activating cascades associated with folliculitis decalvans pathogenesis, preventing further hair follicle destruction.

The therapeutic cyclosporin dose for folliculitis decalvans has not yet been systematically evaluated. The patients in this series responded to doses lower than the standard dosing used in other skin and systemic disorders $(3.5-5 \mathrm{mg} / \mathrm{kg} /$ day). Initial treatment response by our first 
patient at a low dose prompted treatment initiation at lower doses for subsequent patients in this series. Other immunosuppressive treatment approaches could also be considered for patients with refractory folliculitis decalvans, as demonstrated by our recent case series using tofacitinib. ${ }^{5}$

Our study is limited by small sample size and use of concomitant medication. Further studies are required to further evaluate the safety and effectiveness of ciclosporin in folliculitis decalvans as well as standardise a therapeutic dose. Our findings suggest ciclosporin may be a treatment option for folliculitis decalvans, particularly when activity persists despite antibacterial treatment or conventional immunosuppression.

\section{REFERENCES}

1. Harries MJ, Sinclair RD, MacDonald-Hull S, Whiting DA, Griffiths CEM, Paus R.

Management of primary cicatricial alopecias: options for treatment. Br J Dermatol. 2008;159(1):1-22. doi:10.1111/j.1365-2133.2008.08591.x

2. Faulds D, Goa KL, Benfield P. Cyclosporin: A Review of its Pharmacodynamic and Pharmacokinetic Properties, and Therapeutic Use in Immunoregulatory Disorders. Drugs. 1993. doi:10.2165/00003495-199345060-00007

3. Rambhia PH, Conic RRZ, Murad A, Atanaskova-Mesinkovska N, Piliang M, Bergfeld W. Updates in therapeutics for folliculitis decalvans: A systematic review with evidencebased analysis. J Am Acad Dermatol. 2019;80(3):794-801.e1. doi:10.1016/j.jaad.2018.07.050

4. Chiarini C, Torchia D, Bianchi B, Volpi W, Caproni M, Fabbri P. Immunopathogenesis of folliculitis decalvans: Clues in early lesions. Am J Clin Pathol. 2008;130(4):526-534. doi:10.1309/NG60Y7VOWNUFH4LA

5. Jerjen R, Meah N, Trindade de Carvalho L, Wall D, Sinclair R. Folliculitis decalvans responsive to tofacitinib: A case series. Dermatol Ther. 2020;(June):3-5. doi:10.1111/dth.13968

This article is protected by copyright. All rights reserved 


\begin{tabular}{|c|c|c|c|c|c|c|}
\hline Patient & $\begin{array}{l}\text { Disease } \\
\text { duration, y }\end{array}$ & Previous treatments & Daily CSA Dose & $\begin{array}{l}\text { CSA Duration, } \\
\text { months }\end{array}$ & Concurrent treatment* & $\begin{array}{l}\text { Adverse } \\
\text { events }\end{array}$ \\
\hline 1 & $\int^{5}$ & $\begin{array}{l}\text { Minocycline, bactrim, rifampicin, fucidin, } \\
\text { finasteride, OM, anti-septic shampoo, } \\
\text { topical clindamycin, intralesional } \\
\text { steroids. }\end{array}$ & $50 \mathrm{mg}$ & 19 & $\begin{array}{l}\text { Finasteride, OM, minocycline, } \\
\text { topical clindamycin, antiseptic } \\
\text { shampoo, intermittent } \\
\text { intralesional steroids. }\end{array}$ & Nil \\
\hline 2 & C & $\begin{array}{l}\text { Plaquenil, isotretinoin, doxycycline, } \\
\text { rifampicin, fucidin, cephalexin, } \\
\text { erythromycin, topical clindamycin, } \\
\text { antiseptic shampoo, topical } \\
\text { corticosteroids, intralesional steroids. }\end{array}$ & $50 \mathrm{mg}$ & 28 & $\begin{array}{l}\text { Isotretinoin (19 months), oral } \\
\text { prednisolone ( } 1 \text { month), topical } \\
\text { corticosteroids, intralesional } \\
\text { corticosteroids, topical } \\
\text { clindamycin, bactrim }\end{array}$ & $\begin{array}{l}\text { Elevated } \\
\text { creatinine } \\
(1.4 \times U L N) \text {, } \\
\text { reduced GFR }\end{array}$ \\
\hline 3 & 9 & $\begin{array}{l}\text { Isotretinoin, topical clindamycin. Oral } \\
\text { antibiotics (name unknown) }\end{array}$ & $\begin{array}{l}100 \mathrm{mg} \text { ( } 2 \text { months) } \\
125 \mathrm{mg} \text { ( } 2 \text { months) } \\
150 \mathrm{mg} \text { ( } 2 \text { months) }\end{array}$ & 6 & OM, antiseptic shampoo & Nil \\
\hline
\end{tabular}

Table 1: Clinical, demographic and treatment details of three patients with folliculitis decalvans responsive to ciclosporin (CSA)

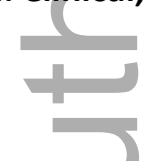

Abbreviations: CSA, ciclosporin: GFR, Glomerular Filtration Rate; OM, oral minoxidil; ULN, Upper Limit of normal; y, years

* Concurrent therapies were continued throughout whole ciclosporin treatment duration unless otherwise specified and do not represent novel treatments but rather a continuation from pre-ciclosporin.

This article is protected by copyright. All rights reserved 


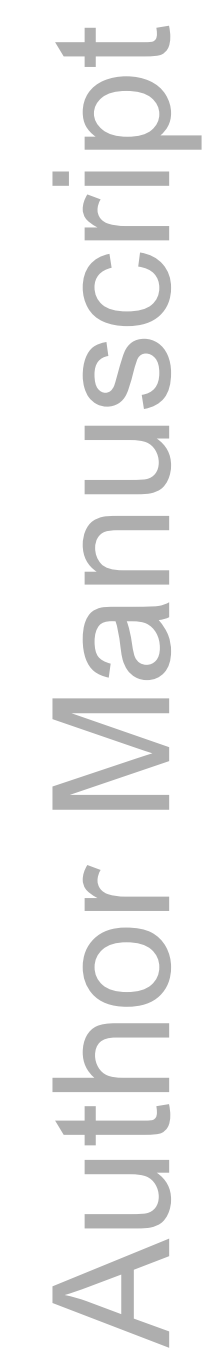

This article is protected by copyright. All rights reserved 
Figure 1: Ciclosporin treatment response in a 30 -year-old male with recalcitrant folliculitis decalvans (Case 3).

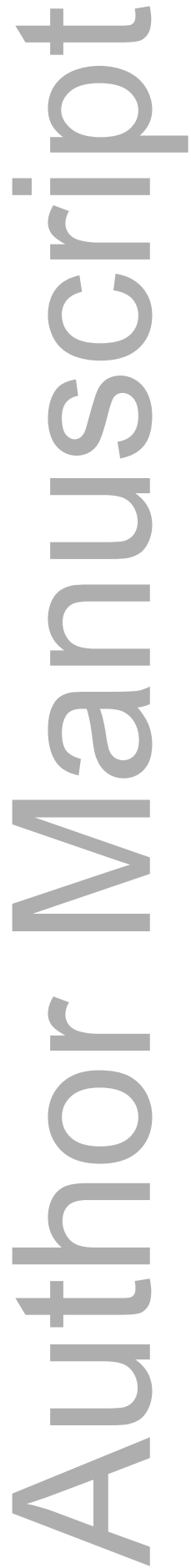

This article is protected by copyright. All rights reserved 


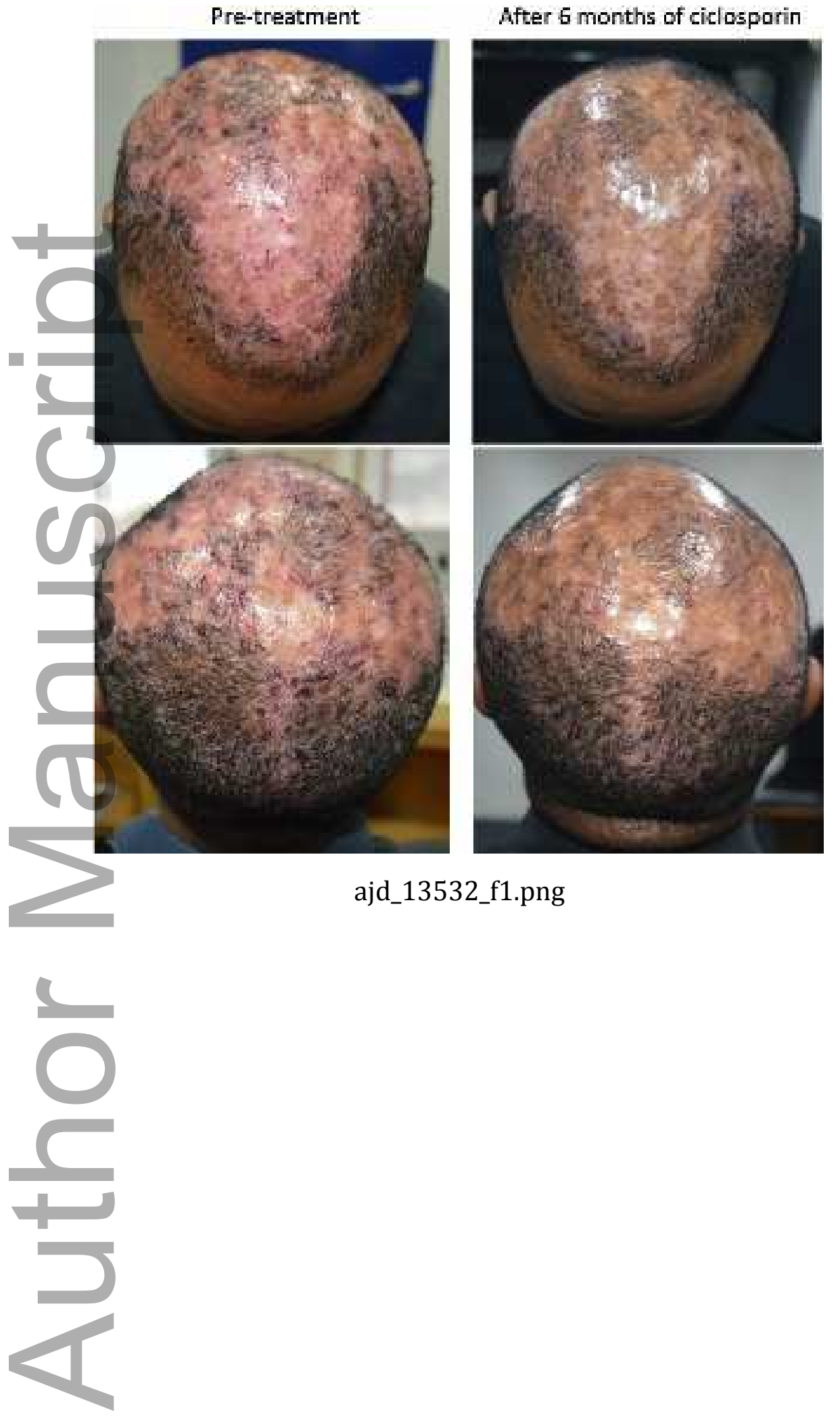

This article is protected by copyright. All rights reserved 


\section{University Library}

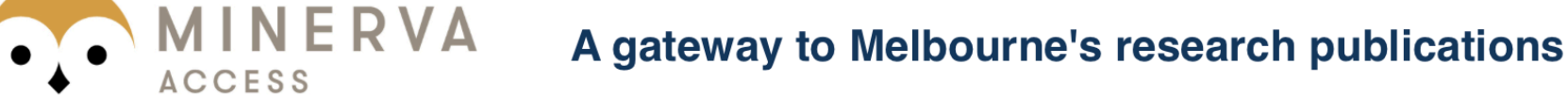

Minerva Access is the Institutional Repository of The University of Melbourne

Author/s:

Jerjen, R;Meah, N;de Carvalho, LT;Wall, D;Gunatheesan, S;Sinclair, R

Title:

Effective treatment of folliculitis decalvans with cyclosporin: A case series

Date:

2021-05-01

Citation:

Jerjen, R., Meah, N., de Carvalho, L. T., Wall, D., Gunatheesan, S. \& Sinclair, R. (2021).

Effective treatment of folliculitis decalvans with cyclosporin: A case series. AUSTRALASIAN

JOURNAL OF DERMATOLOGY, 62 (2), pp.E345-E347. https://doi.org/10.1111/ajd.13532.

Persistent Link:

http://hdl.handle.net/11343/278521 